115. ラクビーのパスに閏する研究 一正確さと, 距離の関係について一

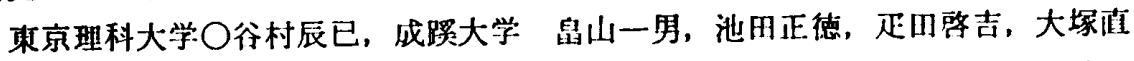

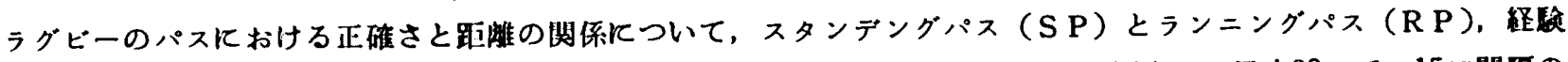

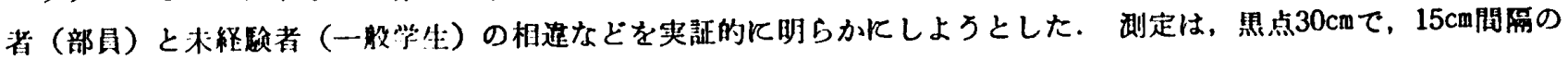
5 圈的の“まと”に対し，2 $\mathrm{m}$ おきに各 5 回宛それぞれのパスを行つた.

〈桔果〉S P は，部員で $6 \mathrm{~m}$ までは余り正確さが头われない，以後は急に落ちて，14mで19\%が届かなくなつた未

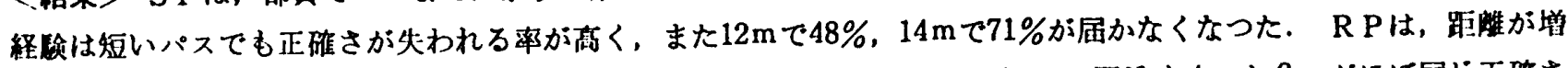
大するとつれ，ほほ同じ差で正確さは低下する．未経駼者の $2 \mathrm{~m}$ と部号の $4 \mathrm{~m}$ ，同じく $4 \mathrm{~m}$ と $8 \mathrm{~m}$ がほ同じ正確さ

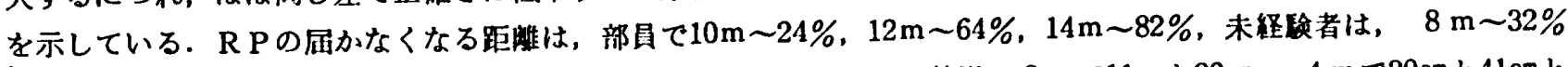

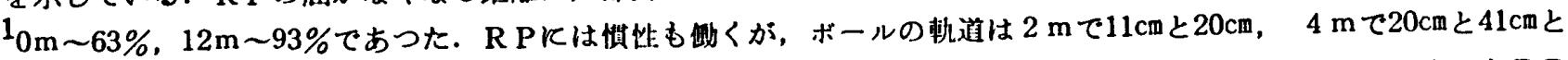

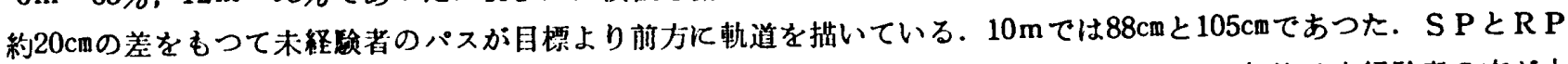

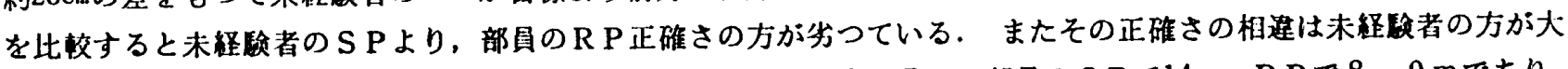

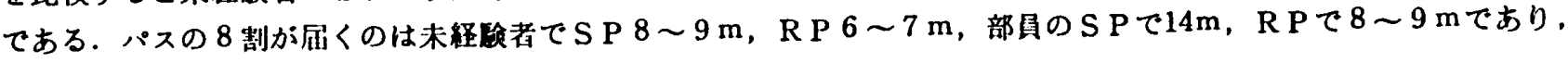



\title{
116. ラクヒーにおけるフツキンク動作の分析的研究
}

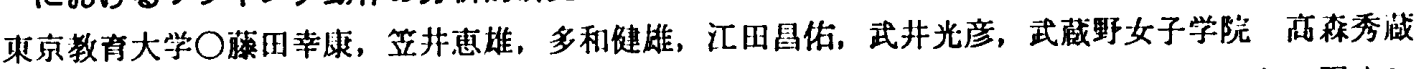
〈研究の目的〉（１）条件をつけないで行なつたフッキング（（I）ボールのバウント地点をルール通りに限定し， ヘ ッキング足の位蜀を前飞移動して行なつたフッキング，（II），（II）の条件でインパクトする埸合，ボールKミートする

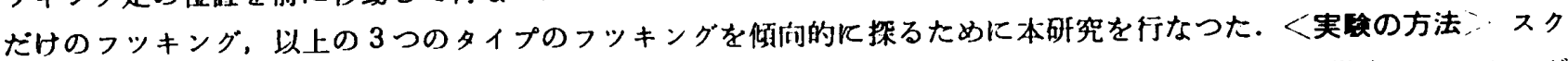

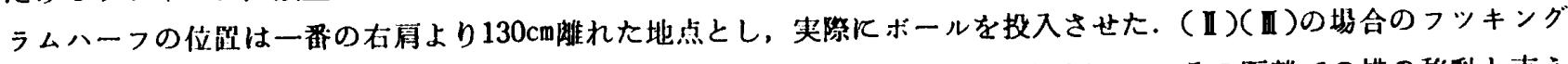



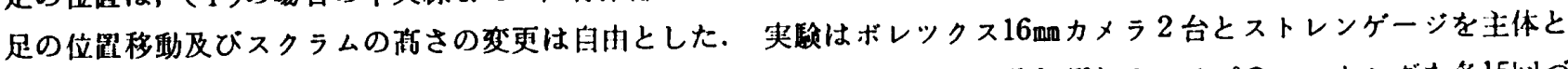


つ試技させた：〈桔果〉ルールK定められているものにより近つくくための傾向として(1)ッキング足を前に，また， 多少 3 番よりに明いて位面した方がい，(2)フック䎲怍は小さく，またはないうがよく，フッキング是の移動速度は


なボールの股入泣を工夫する必整がある。

\section{7. 「ラカーマンの競技・生活・意識についての一考察」}

九州速科大学: 14 本 批 治

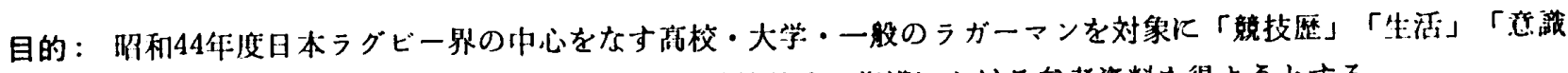

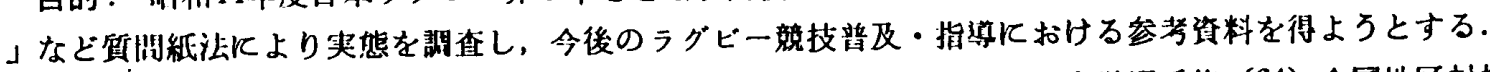


さらに全日次強化絉習参加渚（43）の643名。

結果・考察：少略

まとめ：今後のラグピ一競技普及・指導上とくに次の事柄が考えられる.


し,一般大采飞理!解を深めさせる.

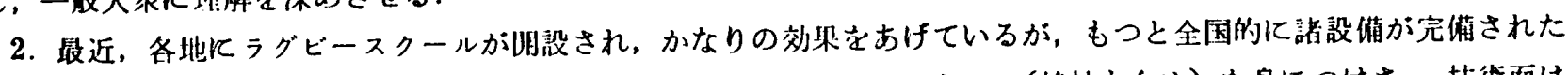

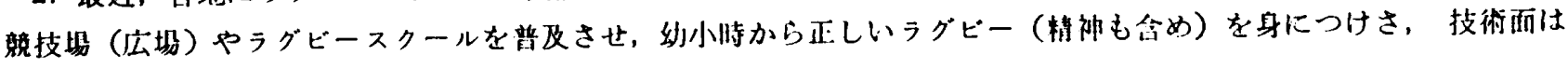

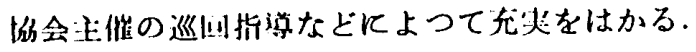

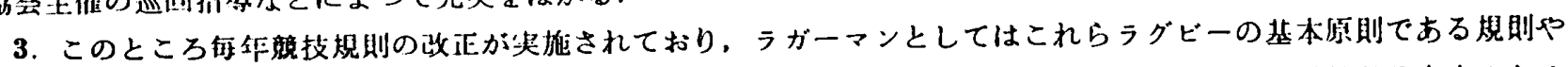


もつとも重要なことであると考えられる。 